\title{
KARAKTERISTIK HIDRO-OSEANOGRAFI BUDIDAYA KERANG MUTIARA MABE (Pteria penguin) DI PERAIRAN PALABUSA SELAT BUTON KOTA BAU-BAU
}

\author{
Characteristics of Hydro-Oceanography Forpearl Cultivation \\ of Mabe (Pteria Penguin ) in Palabusa Seawater, Buton Strait, Bau-Bau
}

\author{
Jawadin ${ }^{1}$, Muhammad Ramli ${ }^{2}$, La Ode Alirman $\mathrm{Afu}^{3}$ \\ ${ }^{1}$ Mahasiswa Jurusan Ilmu Kelautan, \\ Fakultas Perikanan dan Ilmu Kelautan, Universitas Halu Oleo. \\ Jl. H.E.A Mokodompit Kampus Hijau Bumi Tridharma Anduonohu Kendari 93232, Telp/Fax: (0401) 3193782 \\ ${ }^{2}$ Surel:muh.ramli@gmail.com \\ ${ }^{3}$ Surel: alirmanotsudari@yahoo.com
}

\begin{abstract}
Abstrak
Karakteristik hidro oseanografi merupakan salah satu faktor pembatas dalam usaha budidaya kerang mutiara mabe (Pteria penguin). Penelitian ini bertujuan untuk mengetahui karakteristik hidro oseanografi pada lokasi budidaya kerang mutiara mabe di Kelurahan Palabusa Kota Baubau. Pengambilan data dilaksanakan pada bulan September 2018-Oktober 2018 melalui pengukuran langsung di lapangan. Parameter kimia di analisis di Laboratorium. Data di analisis secara desktiptif untuk mengetahui karakteristik parameter hidro oseanografi terhadap aktivitas budidaya kerang mutiara mabe. Hasil analisis menunjukan bahwa nilai kecepatan arus berkisar antara 0,25-0,45 m/detik, kecerahan perairan dengan nilai kisaran $75-90 \%$, kedalaman dengan nilai kisaran $17-21 \mathrm{~m}$, dan suhu dengan nilai kisaran $29^{\circ} \mathrm{C}-34^{\circ} \mathrm{C}$. Sedangkan untuk parameter kimia, kandungan $\mathrm{pH}$ berkisar 7-8, salinitas 33-34 ppt, DO 2,8709-5,7418 mg/L, dan nitrat dengan nilai kisaran 0,0443-0,1337 mg/L. Hasil analisis juga menunjukkan bahwa karakteristik hidro oseanografi di lokasi studi masih sesuai untuk peruntukan kegiatan budidaya kerang mutiara mabe.
\end{abstract}

Kata Kunci: Hidro-oseanografi, bubidaya kerang mabe, Palabusa

\begin{abstract}
Characteristics of hydro oceanographic are one of the limiting factors forpearl cultivation of mabe (Pteria penguin). This study aimed to determine the suitability of hydro oceanography characteristics for pearl cultivation of mabein Palabusa Seawater, Baubau City. Data collection was carried out from September 2018 to October 2018 through direct measurements in the location whilechemical parameters were analyzed in the Laboratory. Data were analyzed descriptively to determine the suitability of hydro oceanographic parameters for pearl cultivation of mabe. Results of the measurement showed that the current velocity ranged from $0.25 \mathrm{~m} /$ detik $-0.45 \mathrm{~m} / \mathrm{detik}$, water brightness ranged $75-90 \%$, water depth rangedfrom $17 \mathrm{~m}-21 \mathrm{~m}$, and temperature rangedfrom $29^{\circ} \mathrm{C}-34^{\circ} \mathrm{C}$. Chemical parameters including $\mathrm{pH}$, Salinity, DO and nitrate ranged from 7-8, 33-34 ppt, 2.87-5.74 mg/L, and 0.04 mg/L-0.13 mg/L respectively. The results also showed that those characteristics are still suitable for pearl cultivation of mabein the study area.
\end{abstract}

Keywords: Hydro oceanographic, pearl cultivation of mabe, Palabusa

\section{Pendahuluan}

Pteria penguin merupakan salah satu organisme laut yang tergolong dalam phylum Mollusca. Organisme laut ini juga dikenal sebagai kerang penghasil mutiara. Karena bentuknya tidak begitu bundar maka penggemarnya hanya pada kalangan masyarakat yang budidaya kerang mabe (Pteria penguin) yang umumnya, hal itu dapat dibuat lebih menarik untuk membuat karya dengan bahan dasar kerang mutiara. Kerang mutiara famili Pteria Penguin adalah salah satu sumberdaya perikanan ekonomis penting sebagai penghasil mutiara. Kerang mutiara mabe (Pteria penguin) dikenal sebagai bahan baku perhiasan yang bernilai ekonomis, selain itu lapisan narce atau yang lebih dikenal sebagai "mother of pearl" pada bagian cangkang kerang dimanfaatkan sebagai bahan ornament yang juga bernilai ekonomis. Pteria maxsima dan pteria margaritifera mutiara yang menghasilkan kerang mabe setengah bulat (bundar), sedangkan Pteria penguin dikenal sebagai bahan penghasil mutiara setengah bundar (hal-pearl).

Kerang mutiara mabe dari genus Pteria (Pteria penguin) adalah kerang yang umum di budidayakan oleh masyarakat baik secara berkelompok maupun antara perorangan untuk menghasilkan mutiara setengah bulat atau yang biasa disebut mabe. Metode budidaya 
kerang mutiara mabe (Pteria penguin) untuk menghasilkan mutiara mabe yang lebih mudah di lakukan dan dapat diajarkan kepada masyarakat dibandingkan dengan mutiara bundar yang memerlukan tenaga ahli yang harus dibayar dengan harga yang relatif tinggi (Haws, 2010).

Budidaya kerang mutiara sudah menunjukkan perubahan yang signifikan terhadap perekonomian masyarakat dan kegiatan budidaya telah mengarah pada kegiatan industri berwawasan lingkungan. Kegiatan budidaya kerang mutiara mabe (Pteria penguin) di laut meliputi, pendederan, pembesaran dan pemeliharaan pasca operasi (pemasukan nucleus). Pendederan adalah pemeliharaan spat yang berasal dari kerang mutiara mabe (Pteria penguin) berukuran 5 $\mathrm{cm}$. Pembesaran kerang mutiara mabe (Pteria penguin) meliputi pemeliharaan kerang mutiara dari ukuran $5 \mathrm{~cm}$ sampai dengan 10 $\mathrm{cm}$ (siap untuk di operasi). Sedangkan pemeliharaan kerang mutiara pasca operasi di mulai dari kerang mutiara mabe berukuran 10 cm sampai dengan panen (18 bulan-24 bulan).

Karakteristik hidro oseanografi pada lokasi budidaya kerang mutiara mabe (Pteria penguin) untuk mendapatkan area budidaya yang sesuai untuk pertumbuhan kerang mutiara mabe (Pteria penguin) memperbaiki karakteristik hidro oseanografi lokasi budidaya, oleh karena itu sangat penting dikaji karakteristik hidro oseanografi lingkungan perairan yang mendukung pertumbuhan kerang mabe (Pteria penguin) diantaranya pasang surut, kedalaman, suhu, kecepatan arus, kecerahan, salinitas, $\mathrm{pH}, \mathrm{DO}$ dan nitrat.

Perairan pantai Palabusa terletak di Selat Buton Kota Baubau yang dikelilingi oleh dua sungai yakni sungai Wonco dan sungai Baubau yang bermuara di perairan pantai Palabusa, sehingga menyebabkan perubahan parameter lingkungan. Dimana setelah hujan lebat aliran sungai Baubau akan berubah menjadi kecoklatan karena mengandung lumpur yang berasal dari kegiatan di daerah hulu sungai. Hal ini mempengaruhi kegiatan budidaya kerang mutiara mabe (Pteria pinguin) di lokasi budidaya tersebut.

Penelitian ini bertujuan untuk mengetahui karakteristik hidro-oseanografi pada lokasi budidaya mutiara mabe $(P$. penguin) di perairan Palabusa Selat Buton, Kota Bau-Bau. Manfaat dari Penelitian nntuk menambah wawasan dan mengaplikasikan pengetahuan dalam bidang pengolahan data karakteristik hidro oseanografi budidaya kerang mutiara mabe (P. penguin). Selain itu, sebagai bentuk sumbangsih dan upaya perwujudan visi Universitas Halu Oleo dalam pengembangan pesisir, kelautan dan pedesaan. Hasil penelitian dapat menjadi referensi dalam melakukan praktek atau penelitian tentang hidro oseanografi khususnya tentang karakteristik hidro oseanografi.

Kerang mutiara mabe ( $P$. penguin) termasuk dalam phylum mollusca, phylum ini terdiri atas 6 klas yaitu: Monoplancohora, Amphineura, Gastropoda, Lamellibrachiata, atau Pellecypoda, Seaphopoda, dan Cephalopoda. Kerang mutiara mabe ( $P$. penguin) merupakan hewan yang mempunyai cangkang yang sangat keras dan tidak simetris. Hewan ini tidak bertulang belakang dan bertumbuh lunak (phillum mollusca). Klasfikasi kerang mutiara mabe (Pteria penguin) menurut Blay et al., (2014), adalah sebagai berikut: Class : Pellecypoda/ Lamellibranchiata; Order : Anysomyaria; Family : Pteridae; Genus : Pteria; Species : Pteria penguin

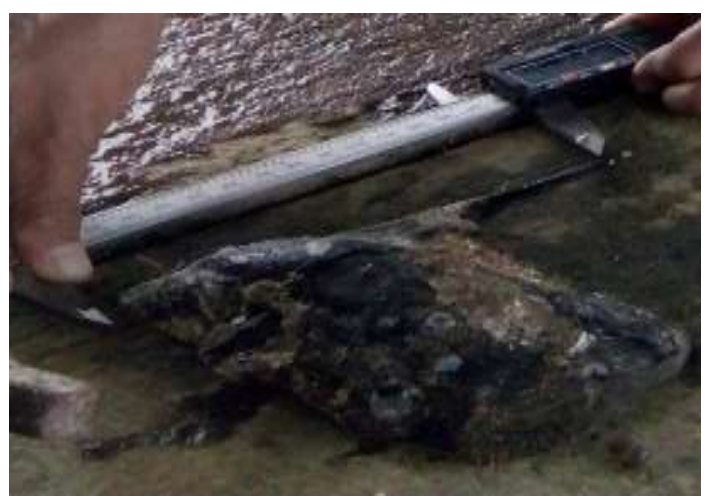

Gambar 1. Klasifikasi Kerang Mutiara Mabe (Pteria penguin)

Kerang dari famili Pteriidae ditandai dengan engsel cangkang yang lurus dengan katup cangkang seperti bersisik. Lebar cangkang (anterior-posterior) dapat lebih panjang dibandingkan dengan tinggi (dorsalventral). Pewarnaan pada lapisan cangkang bagian luar (periostakum) dapat berubah dengan tanda radial (Venkatesan dan Mohamed, 2015).

Kerang mabe ( $P$. penguin) memiliki cangkang yang kuat dan keras, umumnya bewarna coklat gelap sampai hitam. Katup pada bagian kiri lebih cembung dari pada 
bagian kanan, dengan engsel panjang dan lurus (Gervis, 2011).

Secara tradisional kerang mutiara ditentukan berdasarkan tampilan cangkang (bentuk dan warna) yang dikenal sebagai karakter yang mudah dipengaruhi oleh faktor lingkungan dan heterogenitas antara habitat (Cunha et al., 2011). Genus Pteridae secara tradisional juga ditentukan oleh bentuk cangkang. Selain perbedaan dalam bentuk cangkang, genus Pteria dan Pinctada dibedakan oleh pola gigi engsel dan bentuk goresan otot adductor posterior (Victor et al., 1995).

Bivalvi memiliki dua katup cangkang yang dihubungkan oleh engsel pada bagian punggung dan terhubung oleh ligament elastis (Gosling, 2015). Cangkang yang tertutup dengan lapisan organik merupakan scleroprotein dari pinggiran mantel, yang merupakan suatu periostracum yang jarang (Lewbart, 2012). Bagian dorsal cangkang berbentuk datar dan panjang serta dihubungkan oleh semacam engsel berwarna hitam (Takemura dan Kafuku, 1957 dalam Winanto, 2009).

\section{Bahan dan Metode}

Penelitian ini dilaksanakan pada bulan September-Oktober 2018 di perairan Kelurahan Palabusa Selat Buton, Kota BauBau. Analisis sampel dilakukan di Laboratorium Fakultas Perikanan dan Ilmu Kelautan, Universitas Halu Oleo.

Variabel yang diamati dan alat yang digunakan dalam penelitian ini yaitu parameter fisika dan parameter kimia. Parameter fisika meliputi pasang surut di ukur dengan mengunakan tiang berskala, kecepatan arus di ukur dengan mengunakan layang arus, Kecerahan Perairan di ukur dengan mengunakan Secchi disk, Kedalaman di ukur dengan mengunakan alat GPS Map Echosounder, Suhu di ukur dengan mengunakan alat GPS Map Echosounder. Parameter kimia meliputi $\mathrm{pH}$ di ukur dengan mengunakan Kertas $\mathrm{pH}$, Salinitas di ukur dengan mengunakan Handrefractormeter, Oksigen terlarut di ukur dengan mengunakan Titrasi Winkler/DO meter, Nitrat di ukur dengan mengunakan Spektrofotometer.

\section{Hasil dan Pembahasan}

\section{Pasang Surut}

Berdasarkan data sekunder pasang surut yang diperoleh dari Dinas Hidros TNI AL di perairan Palabusa pada lokasi budidaya kerang mutiara mabe ( $P$. penguin) menunjukkan bahwa pasang surut yang terjadi pada lokasi ini memiliki tipe pasang surut campuran (ganda dominan), pasang surut campuran condong harian ganda (mixed tide, prevailing semi diumal). Merupakan pasut yang terjadi dua kali pasang dan dua kali surut dalam sehari, tetapi terkadang terjadi satu kali pasang dan satu kali surut dengan memiliki tinggi dan waktu yang berbeda, sesuai untuk karakteristik lahan budidaya kerang mutiara mabe ( $P$. penguin), serta mendukung keberadaan dan kehidupan kerang mutiara mabe ( $P$. penguin). Hal ini sesuai karakteristik dengan pernyataan Sumarto et al., (2014), bahwa pergerakan pasang surut dengan kondisi dan karakteristik perairan akan mempermudah pergantian penyerapan unsur hara yang diperlukan oleh organisme. Pasang surut juga sangat

Ramalan pasang Surut bedasarkan data komponen pasang surut Hidro Oseanografi TNI AL Kendari pada perairan kelurahan Palabusa disajikan pada Gambar 2.

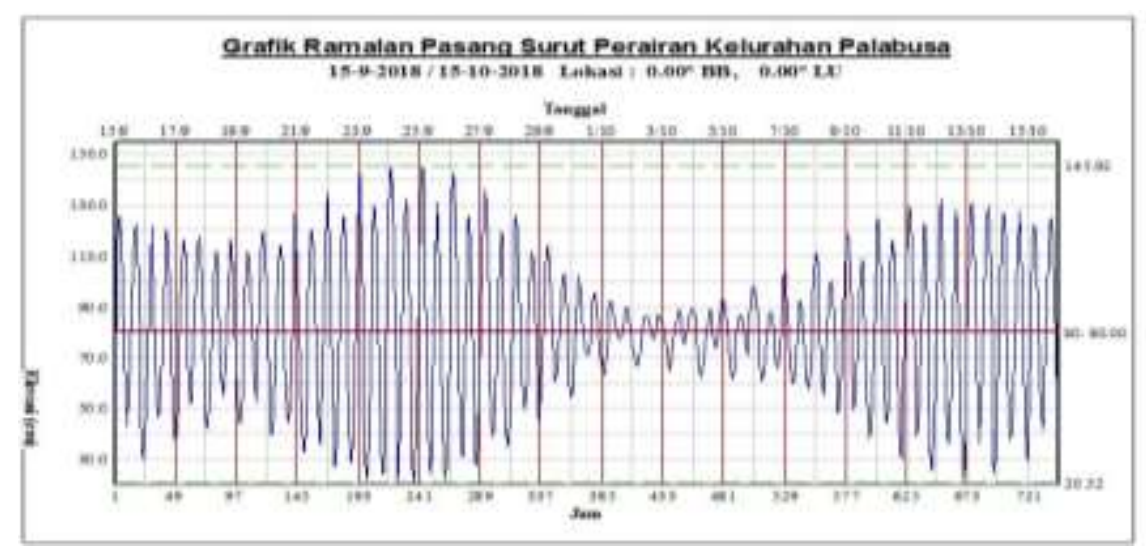

Gambar: 2. Grafik ramalan pasang surut perairan kelurahan palabusa 


\section{Kecepatan Arus}

Hasil pengukuran kecepatan arus (Gambar 3) stasiun I diperoleh nilai kecepatan arus kisaran sebesar 0,25-035 m/detik. stasiun II di diperoleh nilai kecepatan arus kisaran sebesar 0,32-0,45 m/detik. Hal ini menunjukkan bahwa kecepatan arus yang terjadi pada lokasi lahan budidaya kerang mutiara mabe terbilang normal dan sesuai untuk kegiatan budidaya. Dimana arus berperan penting dalam menunjang pertumbuhan budidaya kerang mutiara, terutama dalam sirkulasi nutrien maupun karbondioksida yang diperlukan kerang mutiara untuk melakukan fotosintensis. Namun jika kecepatan arus terlalu tinggi, juga berakibat buruk bagi kerang mutiara. Hal ini sesuai dengan pernyataan Firmansah (2019), bahwa pergerakan arus yang berkisar 0,25$0,50 \mathrm{~m} /$ detik, dengan kondisi karakteristik seperti ini akan mempermudah pergantian dan penyerapan unsur hara yang diperlukan oleh budidaya kerang mutiara.

Berdasarkan hasil pengukuran kecepatan arus yang diperoleh berkisar antara 0,32-0,45 $\mathrm{m} /$ detik pada stasiun II ini menunjukkan bahwa kegiatan budidaya kerang mutiara mabe $(P$. penguin) akan baik dan ketersedian makanan di perairan relatif optimum, sehingga sangat membutuhkan peranan arus perairan yang membawa plankton sebagai makanan alami bagi kerang mutiara. Hal ini sesuai dengan pernyataan Hardinata (2016), bahwa kecepatan arus 0,25 $\mathrm{m} /$ detik merupakan prospek kegiatan budidaya akan baik dan menjamin ketersediaan makanan dialam pada perairan yang terlindung.

\section{Kecerahan}

Berdasarkan hasil penelitian pengukuran kecerahan (Gambar 4) perairan pada stasiun I diperoleh nilai kecerahan kisaran sebesar 70$85 \%$. Stasiun II diperoleh nilai kecerahan kisaran sebesar 75-90\%. Tingkat kecerahan ini termasuk kriteria baik dan sangat ideal untuk budidaya kerang mutiara karena melebihi kedalaman $12 \mathrm{~m}$. Kecerahan ini sangat bagus untuk karakteristik budidaya kerang mutiara. Hal ini sesuai dengan pernyataan Firmansah (2019), bahwa air yang keruh biasanya mengandung lumpur yang dapat menghalangi tembusnya cahaya ke dalam air sehingga akan mengganggu pertumbuhan dan perkembangan kerang mutiara. Lokasi yang baik untuk budidaya kerang mutiara mabe ( $P$. penguin) memiliki kecerahan lebih dari $100 \%$.

Berdasarkan hasil pengukuran kecerahan stasiun I diperoleh nilai kecerahan kisaran sebesar 70-85\%. Stasiun II diperoleh nilai kecerahan kisaran sebesar 75-90\%. Sebaran kecerahan tertinggi terletak pada stasiun II, sedangkan kecerahan terendah pada stasiun I. Hasil pengukuran kecerahan disajikan pada Gambar 4.

\section{$\underline{\text { Kedalaman }}$}

Berdasarkan hasil pengukuran kedalaman stasiun I diperoleh nilai kedalaman kisaran sebesar 12-16 m. Stasiun II diperoleh nilai kedalaman kisaran sebesar 17-21 m. Sebaran kedalaman tertinggi terletak pada stasiun II, sedangkan sebaran terendah terletak pada stasiun I. Hasil pengukuran kedalaman perairan disajikan pada Gambar 5.

Berdasarkan hasil penelitian pengukuran kedalaman (pada stasiun I diperoleh nilai kedalaman kisaran sebesar 12$16 \mathrm{~m}$ dan stasiun II diperoleh nilai kedalaman kisaran sebesar 17-21 m, walaupun adanya perbedaan kedalaman antara dua stasiun pengamatan tersebut layak untuk dijadikan lokasi budidaya kerang mutira, karena pada daerah ini merupakan laut bebas. Serta sangat menunjang pertumbuhan kerang mutiara. Hal ini sesuai dengan pernyataan Winanto (2010), bahwa faktor kedalaman suatu perairan berhubungan erat dengan produktivitas, suhu vertikal, penetrasi cahaya, densitas, kandungan oksigen, serta unsur hara.

\section{$\underline{\text { Suhu }}$}

Berdasarkan hasil penelitian pengukuran suhu (Gambar 6) pada stasiun I diperoleh nilai suhu kisaran sebesar $28-34^{\circ} \mathrm{C}$ dan tasiun II diperoleh nilai suhu kisaran sebesar $29-32^{\circ} \mathrm{C}$, nilai suhu ini masih dalam toleransi pertumbuhan budidaya kerang mutiara. Hal ini sesuai dengan pernyataan Dirjen Perikanan Tangkap (2012), bahwa kerang mutiara dapat tumbuh pada suhu $32^{\circ} \mathrm{C}$. Kemudian diperkuat pendapat yang dikemukakan oleh Firmansah (2019), yang menyatakan bahwa apabila suhu berkisar 28$32^{\circ} \mathrm{C}$ masih dalam batas yang bisa ditolerir oleh kerang mutiara. Sehingga hasil pengukuran suhu tersebut bahwa untuk karakteristik perairan budidaya kerang mutiara pada perairan Kelurahan Palabusa masih dalam kategori sangat baik. 


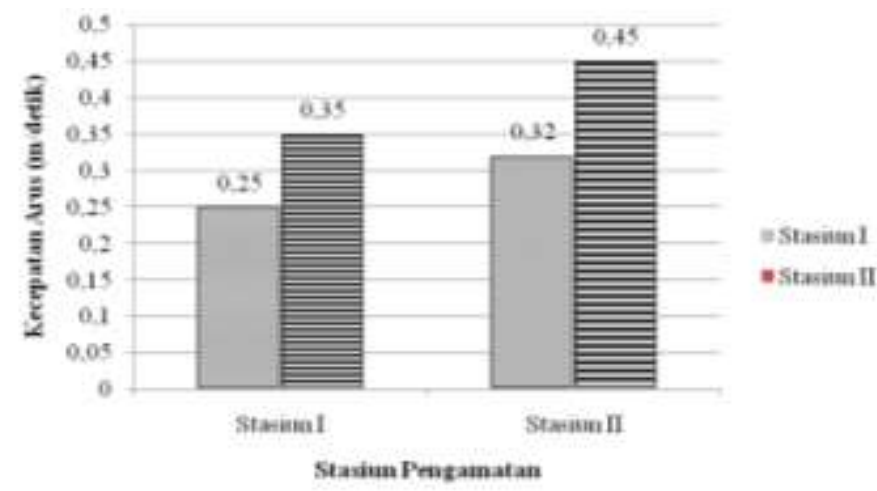

Gambar 3. Hasil Pengukuran Arus pada Lokasi Penelitian

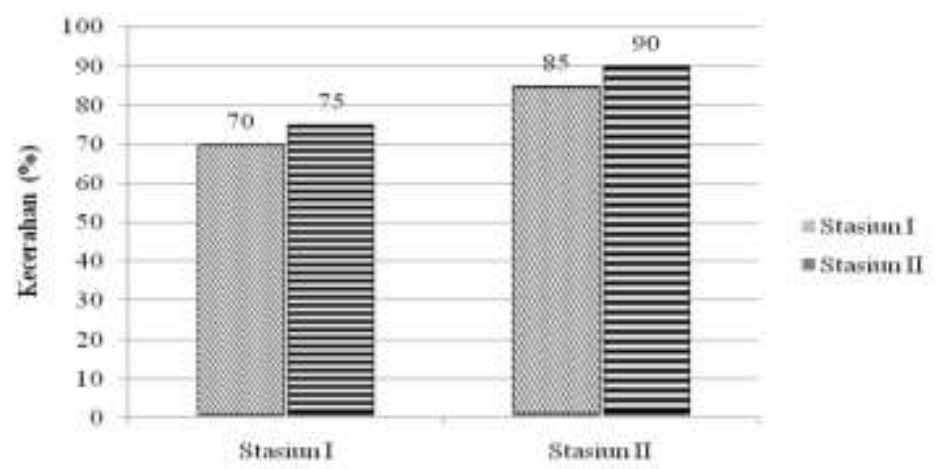

Gambar 4. Hasil Pengukuran Kecerahan pada Lokasi Penelitian

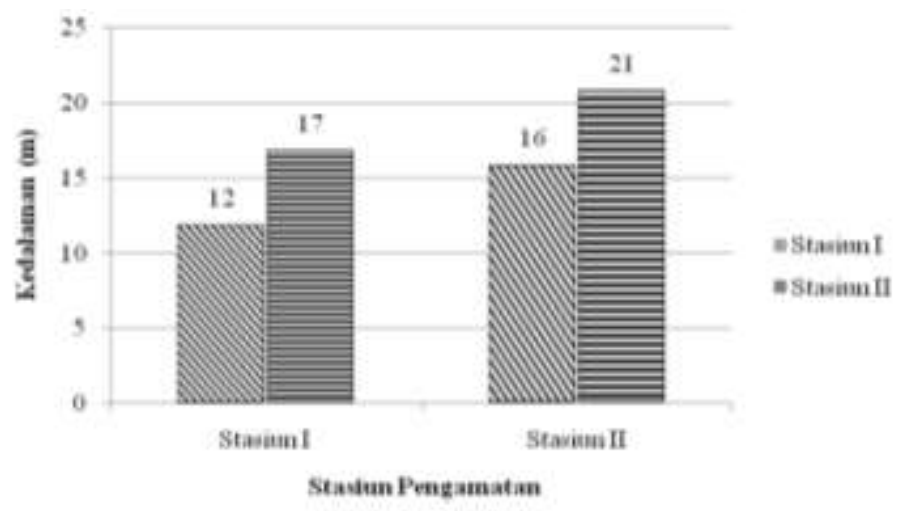

Gambar 5. Hasil Pengukuran Kedalaman pada Lokasi Penelitian

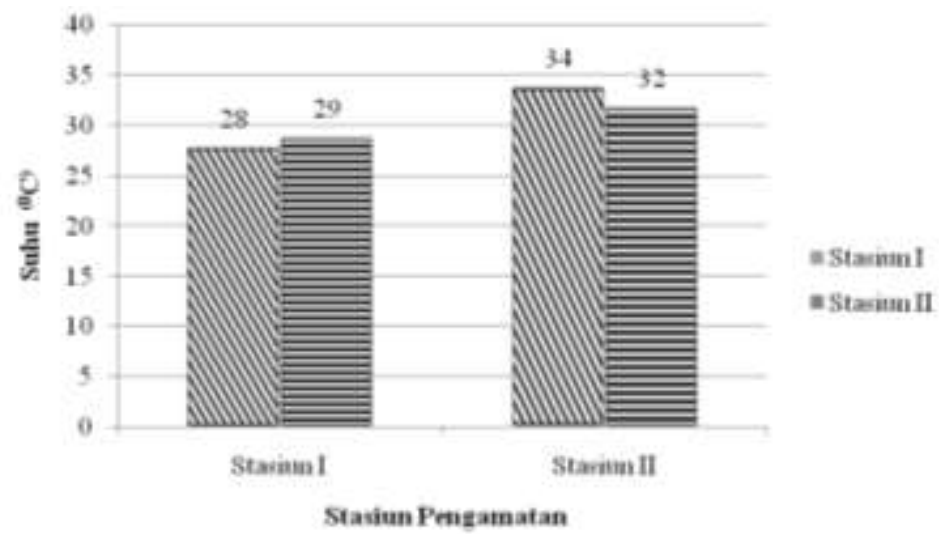

Gambar 6. Hasil Pengukuran Suhu pada Lokasi Penelitian 


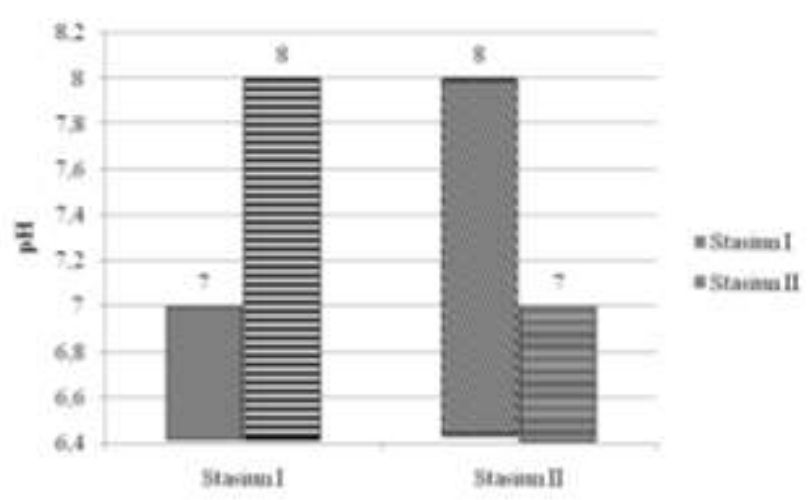

Gambar 7. Hasil Pengukuran pH pada Lokasi Penelitian

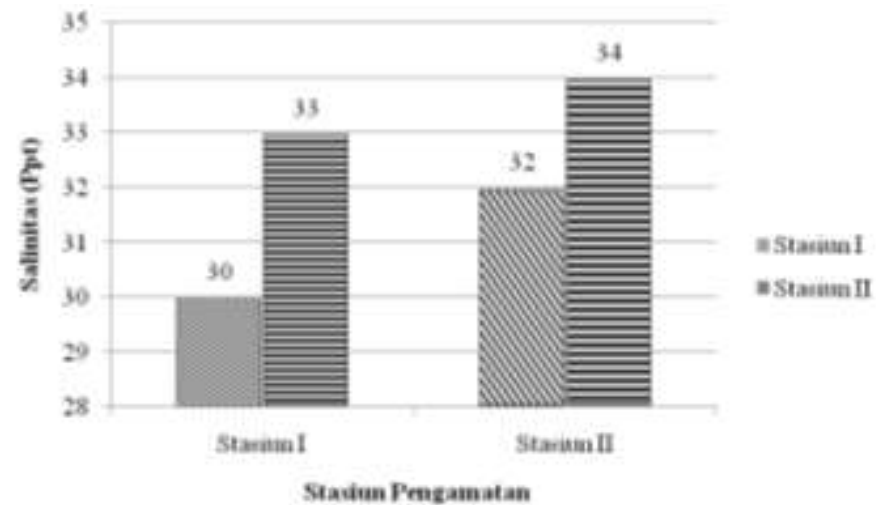

Gambar 8. Hasil Pengukuran Salinitas pada Lokasi Penelitian

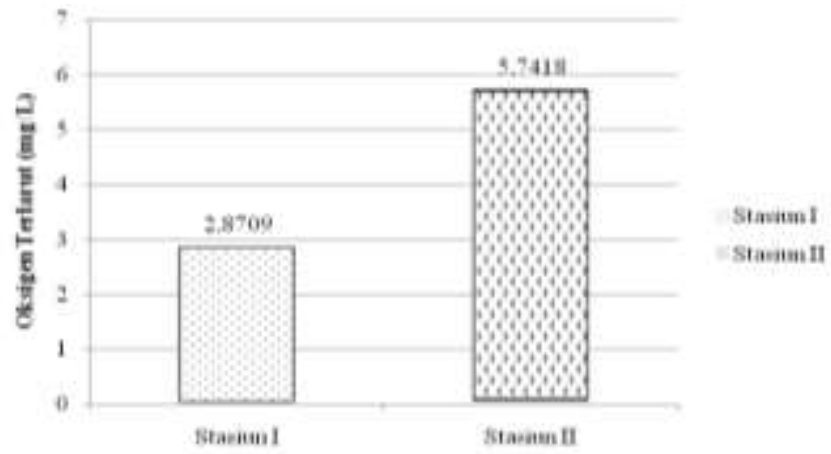

Gambar 9. Grafik Hasil Pengukuran DO

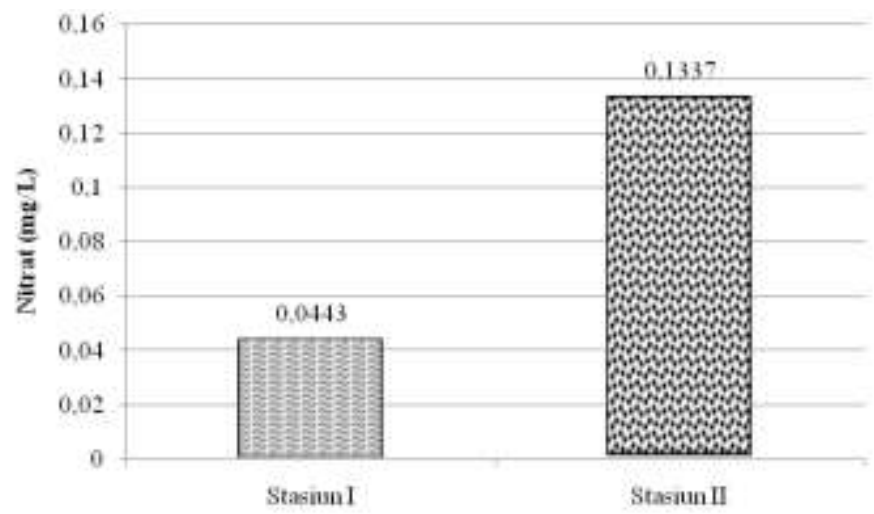

Gambar 10. Grafik Hasil Pengukuran Nitrat 
$\underline{p H}$

Pengukuran konsentrasi $\mathrm{pH}$ (derajat kesamaan) pada stasiun I perairan lokasi pengamatan didapatkan nilai kisaran sebesar 7 $8 \mathrm{pH}$, sedangkan pada pengukuran $\mathrm{pH}$ di stasiun II didapatkan nilai kisaran sebesar 8-7 $\mathrm{pH}$, nilai $\mathrm{pH}$ ini masih dalam toleransi pertumbuhan budidaya kerang mutiara. Perairan Palabusa Selat Buton memiliki sebaran spesial $\mathrm{pH}$ perairan berkisar antara 7-8 pH pada Bulan September dan Bulan Oktober. Nilai pH perairan pada lokasi penelitian memperlihatkan kisaran yang mendukung untuk kegiatan budidaya kerang mutiara. Hal ini sesuai dengan pernyataan Rosanawita (2017), bahwa pH yang layak untuk kehidupan kerang mutiara berkisar antara 7.8-8.6 pH. $\mathrm{pH}$ kerang mutiara dapat berkembang dan tumbuh dengan baik untuk hidup kerang mutiara adalah pada $\mathrm{pH}$ 7.8-8.7.

\section{$\frac{\text { Salinitas }}{\text { Peng }}$}

Pengukuran kandungan salinitas pada stasiun I di lokasi penelitian menunjukan nilai berkisar 30-32 ppt, sedangkan pada pengukuran salinitas stasiun II dengan nilai kisaran sebesar 33-34 ppt, dimana pada pengukuran salinitas yang tinggi terdapat pada stasiun II, dan salinitas terendah pada stasiun I. Hasil penelitian pengukuran salinitas (Gambar 8) pada stasiun I berkisar antara 30-32 ppt, sedangkan pada pengukuran salinitas stasiun II dengan niliai kisaran sebesar 33-34 ppt, hal ini sangat sesuai untuk karakteristik perairan Palabusa serta menunjang pertumbuhan budidaya kerang mutiara mabe. Oleh karena itu, lokasi budidaya kerang mutiara diusahakan jauh dari sumber air tawar seperti dekat muara sungai karena dapat menurunkan salinitas. Hal ini sesuai dengan pernyataan Firmansah (2019), bahwa salinitas yang dikehendaki oleh kerang mutiara yaitu berkisar antara 30-32 ppt.

\section{Oksigen Terlarut (DO)}

Konsentrasi oksigen terlarut (Gambar 9) di perairan Palabusa Selat Buton pada bulan September hingga Oktober berkisar antara 2.8709-5.7418 mg/L. Kisaran nilai oksigen terlarut tersebut mendukung untuk lokasi budidaya kerang mutiara dan sesuai dengan kebutuhan oksigen kerang mutiara. Perbedaan oksigen terlarut pada dua stasiun pengamatan disebabkan oleh pergerakan dan percampuran massa air serta siklus harian. Hal ini sesuai dengan pernyataan Yusuf (2005), bahwa kondisi oksigen terlarut yang optimal dibutuhkan oleh budidaya kerang mutiara mabe (P. penguin) kisaran antara $2.0-3.5 \mathrm{mg} / \mathrm{L}$. Didukung oleh pernyataan Indriani dan Sumiarsih (1991), bahwa pertumbuhan lebih baik jika oksigen terlarut berada di atas 4 $\mathrm{mg} / \mathrm{L}$.

Oksigen terlarut di perairan Palabusa di topang oleh aktifitas fotosintesa mikroalga dan difusi oksigen. Akan tetapi oksigen terlarut merupakan variabel yang dinamis dalam perairan Palabusa, sehingga sangat berkaitan dengan siklus hariannya. Kondisi tersebut yang menyebabkan perbedaan kandungan oksigen terlarut. Hal ini sesuai dengan pernyataan Naik dan Emery (2015), bahwa kandungan oksigen yang terlarut dalam perairan yang merupakan suatu komponen utama bagi metabolisme organisme perairan yang digunakan untuk pertumbuhan, reproduksi, dan kesuburan alga. Disamping itu, daerah yang terbuka lebih memudahkan terdifusinya oksigen ke dalam perairan walaupun kontribusinya di perairan lebih kecil dibandingkan dengan mikroalga.

\section{Nitrat}

Konsentrasi nitrat (Gambar 10) di perairan Palabusa Selat Buton pada Bulan September dan Oktober berkisar 0.0443$0.1337 \mathrm{mg} / \mathrm{L}$. Kisaran nilai nitrat tersebut mendukung untuk lokasi budidaya kerang mutiara. Hal ini sesuai dengan pernyataan Taufiq et al., (2007), bahwa kandungan nitrat yang cocok untuk budidaya kerang mutiara berkisaran $0.02-0.04 \mathrm{mg} / \mathrm{L}$. Akan tetapi nitrat merupakan variabel yang dinamis dalam perairan, sehingga sangat berkaitan dengan siklus hariannya. Kondisi tersebut akan menyebabkan perbedaan nilai kandungan nitrat jika waktu pengukuran tidak sama. Hasil pengukuran nitrat pada lokasi budidaya kerang mutiara dengan nilai rata-rata $0.02-0.04 \mathrm{mg} / \mathrm{L}$. Nilai ini sesuai dengan kebutuhan nitrat kerang mutiara yaitu $<0.1 \mathrm{mg} / \mathrm{L}$ dan $4.5 \mathrm{mg} / \mathrm{L}$.

Berdasarkan uraian tersebut karakteristik oseanografi kimia pertumbuhan kerang mutiara mabe ( $P$. penguin) dapat berpengaruh pada kualitas perairan budidaya kerang mutiara mabe $(P$. penguin) di perairan Palabusa seperti $\mathrm{pH}$, salinitas, DO dan Nitrat. Hal ini sesuai dengan pernyataan Firmansah (2019), bahwa pertumbuhan dan karakteristik lahan budidaya yang berpengaruh terhadap parameter oseanografi kimia di perairan. 
Karakteristik Hidro Oseanografi Budidaya

Kerang Mutiara Mabe Perairan Palabusa Selat Buton Kota Bau-Bau

Karakteristik hidro oseanografi budidaya kerang mutiara mabe perairan Palabusa Selat Buton Kota Bau-Bau masih dalam taraf normal untuk pertumbuhan dan perkembangan kerang mutiara mabe $(P$. penguin), akan tetapi terdapat beberapa parameter yang berada di bawah atau di atas batas normal standar mutu yang di sarankan. Beberapa yang berada di bawah atau di atas batas normal standar mutu adalah pasang surut, kecepatan arus, kecerahan perairan, kedalaman, dan suhu. Berdasarkan hasil pengukuran parameter hidro oseanografi perairan Palabusa Selat Buton memperlihatkan kisaran nilai yang berada dalam nilai kisaran optimum, dan sebagian berada dibawah atau melebihi nilai optimum untuk yang bersentuhan.

Nilai parameter hidro oseanografi untuk Perairan Kelurahan Palabusa Selat Buton Kota Bau-Bau menunjukkan beberapa diantaranya berada pada kisaran yang optimum untuk budidaya tiram mutiara $(P$. penguin). Walaupun demikian, beberapa parameter yang kurang memenuhi karakteristik dalam mendukung kegiatan budidaya. Pada variabel primer, parameter kecepatan arus dan kepadatan lokasi budidaya berada di bawah nilai optimum, sedangkan sebagian kedalaman perairan Palabusa termasuk dalam batas optimum. Sementara parameter yang termasuk dalam variabel sekunder yang sebagian perairan tidak memenuhi kadar optimum adalah suhu. Sedangkan kecerahan sebagian besar perairan melebihi batas nilai optimum. Pada variabel tertier, kadar nitrat tidak memenuhi kadar optimum dan DO melebihi kadar optimum untuk budidaya kerang mutiara. Kondisi yang serupa juga terjadi di perairan Palabusa, tetapi suhu perairan telah memenuhi kadar optimum, sedangkan kecerahan melebihi batas optimum. Perairan Palabusa juga memiliki kondisi yang serupa namun parameter kadar material padatan tersuspensi dan kecerahan melebihi nilai optimum, serta kecepatan arus memenuhi nilai optimum.

\section{Simpulan}

Berdasarkan hasil penelitian dapat disimpulkan bahwa karakteristik hidro oseanografi budidaya kerang mutiara mabe
(P. penguin) di perairan Palabusa Selat Buton, Kota Bau-bau mempengaruhi kelangsungan hidup, perkembangbiakan, pertumbuhan dan produksi dari budidaya kerang mutiara mabe $(P$. penguin), dimana hasil analisis menunjukan bahwa nilai kecepatan arus berkisar antara 0,25-0,35 m/detik, kecerahan perairan dengan nilai kisaran $75-90 \%$, kedalaman dengan nilai kisaran 17-21 m, dan suhu dengan nilai kisaran $29^{\circ} \mathrm{C}-34^{\circ} \mathrm{C}$. Sedangkan untuk parameter kimia, kandungan pH berkisar 7-8, salinitas 33-34 ppt, DO 2,8709-5,7418 $\mathrm{mg} / \mathrm{L}$, dan nitrat dengan nilai kisaran 0,0443-0,1337 mg/L. Hasil analisis juga menunjukkan bahwa karakteristik hidro oseanografi di lokasi studi masih sesuai untuk peruntukan kegiatan budidaya kerang mutiara mabe.

\section{Daftar Pustaka}

Blay, C., M. Sham-Koua, V. Vonau, R. Tetemu, P. Cabral, C.L. Ky, 2014. Influence of nacre deposition rate on cultured pearl gradeand colour in the black-lipped pearl oyster Pinctada margaritifera using farmed donor families. Aquaculture international, vol. 22 (2):937-953.

Cunha, R.L., Blance, F., Bonhomme, F., and Arnaud-Haond, S. 2011. Evolutionary Pattern in Pearl Oyster of the Genus Pinctada (Bivalvia: Pteriidae). Mar Biotechnol, 13:181-192.

Dirjen Perikanan Tangkap, DKP. 2012. Petunjuk teknis budidaya laut: kerang mutiara mabe (pteria penguin). Jakarta.

Firmansah, F., 2019. Pengaruh luas Pemiliharaan Terhadap Pertumbuhan Cangkang dan Pelapisan Mutiara Mabe pada Karang Pteria penguin Pasca Implatasi Inti Tesis. PPS UHO. Kendari, 69 hal.

Gervis dan Sing, 2010. The Biology and culture of Pearl Oysters (Bivalvia: Pteriidae). ICLARM Studies and review 21. The Overseas Development. Philippines.

Gervis, M. H. dan Sims, N. A., 2011. The biology and culture of pearl oyster (Bivalvia Pteriidae), International Center for Living Aquatic Resources Management and Review, Manila, Philipines. 56hal.

Gosling, E. 2015. Marine Bivaalve Mollusca Second Edition. Wiley Blackwell, 537 pp. 
Haws, Maria. C. And Ellis, Simon. 2010. Aquafarmer information sheet: collecting black-lip pearl oyster spat. CTSA Publication No. 144.

Hardinata, M. S. 2009. Studi pertumbuhan dan kelangsungan hidup anakan kerang mutiara (Pinctada maxima) dengan menggunakan keranjang tento pada kedalaman yang berbeda di teluk Kodek, Lombok Barat. Prosiding Pertemuan Ilmiah Tahunan ISOI 2008, Bandung : 232-239.

Lewbart, G. A. 2012. Invertebrate Medicine, Second Edition, Wiley Blackwell. 502p.

Naik, G. L. dan W. J. Emery, 2015. Descriptive Physical Oceanography: An Introduction (4 ${ }^{\text {th }}$ Edition). Pergamon press. USA. 249 hal.

Rosanawita, 2017. Laporan Penelitian Pengembangan Standar Budidaya Tiram Mutiara: Teknik Insersi. Jakarta

Sumarto, Hariyadi. P, Purnomo, E, H. (2014). Kajian Proses Perumusan Standar dan Peraturan Keamanan Pangan di Indonesia. Jurnal Pangan. Vol 23, No 2 (2014).

Taufiq, N., Hartati, R., Cullen, J., Masjhoer, J, M. 2007. Pertumbuhan Tiram Mutiara (Pinctada maxima) pada kepadatan berbeda. Ilmu Kelautan. Maret 2007. Vol. 12 (1): 31 - 38.

Vankatesan, Mohamed, Victor, A.C.C., 2015. Ecology of pearl oyster beds and pearl fisheries of India.Dalam : Appukutan, K.K. (eds). Recent advances in mussel and edible oyster farming and marine pearl production (Winter school). CMFRI, Kochi : 40-42.

Winanto T. 2009. Kajian perkembangan larva dan pertumbuhan spat tiram mutiara Pinctada maxima (Jameson) pada kondisi lingkungan pemeliharaan berbeda. Thesis. Sekolah Pascasarjana IPB. Bogor. 